\title{
Nye perspektiver for grønlandsarbejdet
}

\author{
Martin Ghisler
}

Direktør

I et tilbageblik over 1994 overskygges alle andre begivenheder i GGU af én ting: fusionen mellem Grønlands Geologiske Undersøgelse (GGU) og Danmarks Geologiske Undersøgelse (DGU) til Danmarks og Grønlands Geologiske Undersøgelse. Den nye institutions navn forkortes til GEUS (GEologisk UnderSøgelse). I forbindelse med regeringsdannelsen den 27 . september blev energiministeriet sammenlagt med miljøministeriet. Miljø- og energiminister Svend Auken fremsatte ønsket om en sammenlægning af DGU og GGU til én national geologisk undersøgelse. Begge institutioner gik ind for en fusion, et strukturudvalg blev nedsat og de nødvendige lovændringer forberedt. En fusion gennemførtes medio 1995, dog indtil videre med en lokalemæssig placering to steder.

Ved sammenlægning af de to geologiske undersøgelser skabes der én national geologisk undersøgelse dækkende et bredt spektrum af geologiske fagdiscipliner. Fusionen forventes især at styrke klimaforskningen og indsatsen i Grønland på det oliegeologiske område.

I slutningen af året blev det aftalt at udstationere to geologer i en to-årig periode ved Hjemmestyrets råstofkontor i Nuuk, med tiltrædelse i efteråret 1995.

En anden vigtig begivenhed var etableringen af det nye forskningscenter, Dansk Lithosfærecenter (DLC), pr. 1. februar 1994. DLC er finansieret af Danmarks Grundforskningsfond med en 5 -årig bevilling på i alt 70 mill. kr. og er administrativt tilknyttet GGU. Aktiviteterne var i 1994 rettet mod pladetektoniske studier i Vest- og Østgrønland, i nært samarbejde med GGU, Geologisk Institut og Geologisk Museum ved Københavns Universitet samt en række forskningsinstitutioner $i$ andre lande.

GGU har sammen med Råstofforvaltningen for Grønland udført en målrettet informationsvirksomhed over for den internationale olie- og mineindustri. Denne har blandt andet omfattet præsentation af resultater og geologiske forhold af relevans for råstofefterforskningen på møder, symposier, udstillinger og lignende arrangementer samt ved udsendelse af nyhedsbrevene Ghexis (kulbrinter) og Minex (mineraler), og iøvrigt ved en hurtig formidling af geodata på digital form eller gennem rapporter.

GGU har i løbet af sommeren og efteråret på Råstofforvaltningens vegne ført tilsyn med følgende selskabers boreaktiviteter: Falconbridge Greenland $\mathrm{A} / \mathrm{S}$ på Nuussuaq og Disko, GrønArctic Energy Inc. på Nuussuaq og Platinova A/S ved Citronen Fjord i Nordgrønland. GGU har des- uden udført udrednings- og rådgivningsopgaver for råstofforvaltningen vedrørende de geologiske aspekter af råstofudviklingen i Grønland. GGU har bidraget med en række foredrag angående oliemulighederne på et seminar for politikerne i Fællesrådet vedrørende mineralske råstoffer i Grønland, efterfulgt af bes $ø$ g i GGU's laboratorier.

Den daværende energiminister, Jann Sjursen, besøgte GGU's feltaktiviteter i det østlige Nordgrønland i dagene mellem den 27. juli og den 2. august 1994. GGU's baselejr ved Centrum $S \emptyset$ modtog endvidere bes $\emptyset \mathrm{g}$ af ni medlemmer af Fællesrådet for mineralske råstoffer sammen med ni politikere og gæster fra det grønlandske Hjemmestyre.

En række geologiske, geokemiske, geofysiske og glaciologiske undersøgelser er blevet gennemført over hele Grønland. I alt har 84 videnskabelige og tekniske medarbejdere deltaget i GGU's ekspeditioner, hvortil kommer DLC's feltaktiviteter (se særskilt beretning af DLC's direktør, H. C. Larsen, i denne rapport). En fast stab på 81 personer suppleret af 16 eksternt finansierede medarbejdere har været tilknyttet institutionen i København. Hertil kommer 12 medarbejdere ved Dansk Lithosfærecenter.

\section{Oliegeologi}

I forbindelse med den geologiske kortlægning i Nordgrønland gennemførtes oliegeologiske unders $\emptyset$ gelser af de palæozoiske og mesozoiske sedimenter, blandt andet med henblik på en vurdering af oliepotentialet på den nordligste del af den østgrønlandske shelf.

De oliegeologiske aktiviteter i Østgrønland blev videreført med detaljerede studier af udvalgte lokaliteter i Jameson Land i samarbejde med Københavns Universitet.

I Vestgrønland blev der gennemført oliegeologiske og geofysiske undersøgelser på Nuussuaq og den østlige del af Svartenhuk Halvø i samarbejde med Københavns Universitet og Aarhus Universitet. Arbejdet var især koncentreret om de områder på Nuussuaq, hvor der er konstateret olierester i basalterne på overfladen. Desuden skulle undersøgelserne skaffe data med henblik på udvælgelsen af de bedste lokaliteter for en stratigrafisk boring i 1995 på Svartenhuk Halvø.

Tolkningen af seismiske data offshore Vestgrønland syd for $68^{\circ} \mathrm{N}$ blev afsluttet og afrapporteret. Af særlig interesse er tilstedeværelsen af såkaldte 'flat spots' ved Fylla Banke vest 
for Nuuk, som muligvis indikerer forekomster af store mængder kulbrinter.

GGU har som konsulent for og i samarbejde med Nunaoil A/S færdiggjort tolkningen af de seismiske data fra Melville Bugten. Disse data tyder på tilstedeværelsen af store strukturer, der vil kunne danne fælder for kulbrinter.

\section{Geologisk kortlægning}

Den systematiske kortlægning i skala 1:500 000 blev videreført med et stort program i det østlige Nordgrønland. Med udgangspunkt i en base ved Centrum $\ \emptyset$ i Kronprins Christian Land blev der foretaget undersøgelser fra Danmarkshavn i syd til Peary Land i nord, med hovedindsats i området fra $78^{\circ}-81^{\circ} \mathrm{N}$. Der var især tale om strukturgeologiske undersøgelser af den kaledonske bjergkæde, samt stratigrafiske og sedimentologiske studier af de sedimentære bjergarter, med deltagelse af en række udenlandske gæsteforskere.

I tilslutning til de råstofgeologiske undersøgelser i Sydgrønland (SUPRASYD projektet) blev kortlægningen af et kortblad i skala 1:100 000 afsluttet.

I Vestgrønland blev der som led i samarbejdet med Dansk Lithosfærecenter foretaget studier af den 'Nagssugtoqidiske bjergkæde' mellem Sisimiut og Disko Bugt, koncentreret omkring aldersbestemmelser og pladetektoniske forhold.

\section{Mineralefterforskning}

De råstofgeologiske undersøgelser i Sydgrønland blev videreført på østkysten med hovedvægt på malmgeologiske, geokemiske og isotopgeologiske studier (projekt SUPRASYD).

I Østgrønland blev der foretaget malmgeologiske undersøgelser i det nordlige Jameson Land. Laboratoriestudieme af de guld-palladium-førende mineraliseringer fra Skaergaard intrusionen blev videreført i samarbejde med $\mathrm{K} \emptyset$ benhavns Universitet.

Der blev foretaget en stor indsamling af kimberlitter $i$ Vestgrønland med henblik på en evaluering af diamantpotentialet i området mellem Maniitsoq og Disko Bugt.
Som en integreret del af de regionale undersøgelser i det $\emptyset$ stlige Nordgrønland blev der gennemført en systematisk indsamling af bæksedimentprøver. Der blev endvidere foretaget studier af kobber- og blyførende bjergartsenheder som opfølgning fra tidligere års geokemiske undersøgelser.

I Inglefield Land nord for Thule forestod GGU et projekt med flybårne geofysiske målinger finansieret af Grønlands Hjemmestyre. Formålet med undersøgelsesprogrammet er over 5 år at tilvejebringe data fra forskellige udvalgte områder til fremme af mineindustriens interesse for efterforskning i Grønland.

\section{Glaciologi}

Som led i den internationale klimaforskning videreførtes GGU's glaciologiske undersøgelser med finansiel st $\varnothing t t e$ fra EU, Nordisk Ministerråd, Statens Naturvidenskabelige Forskningsråd og Dansk Polarcenter. Undersøgelserne, der var koncentreret omkring Nordgrønland (Hans Tausen Iskappe og Kronprins Christian Land) samt Storstrømmen $\emptyset s t$ for Danmarkshavn, blev gennemført i nært samarbejde med forskere fra Niels Bohr Instituttet samt forskere fra Island, Norge, Sverige og Tyskland.

I Vestgrønland blev der med et internationalt forskerhold gennemført studier af palæoklima-forhold på isranden nord for Ilulissat.

GGU var i 1994 atter med i det nordiske Antarktisprogram med deltagelse af en glaciolog i Norsk Polarinstituts ekspedition til Dronning Maud Land.

\section{Publikationer}

I 1994 har GGU udgivet ét regionalgeologisk kort i skala 1:250 000 over området fra Jakobshavn Isbræ til Nuussuaq samt ét sæt temakort (71 stk) over området fra Kap Farvel til Ivituut i skala 1:1 000 000. Der er udkommet ét bind i GGU's Bulletin-serie, fem bind i Rapport-serien og 19 bidrag i Open File-serien. Som resultat af GGU's aktiviteter er der desuden publiceret 57 artikler i internationale tidsskrifter, herunder GGU's Rapport- og Bulletin-serie. 